\title{
PENERAPAN PENDEKATAN PEMBELAJARAN CONTEXTUAL TEACHING AND LEARNING (CTL) PADA MATA PELAJARAN IPS UNTUK MENINGKATKAN HASIL BELAJAR DAN AKTIVITAS BELAJAR SISWA KELAS VIII I SMP NEGERI 3 SINGARAJA TAHUN AJARAN 2016/2017
}

\author{
Kadek Sri Astiti \\ Program Studi Pendidikan Ekonomi, Fakultas Ekonomi \\ Universitas Pendidikan Ganesha \\ Singaraja, Indonesia \\ e-mail: asdekdekas@yahoo.co.id
}

\begin{abstract}
ABSTRAK
Penelitian ini bertujuan untuk meningkatkan (1) hasil belajar siswa dan (2) aktivitas belajar siswa melalui penerapan pendekatan Contextual Teaching and Learning (CTL) pada mata pelajaran IPS di kelas VIII I SMP Negeri 3 Singaraja tahun ajaran 2015/2016 yang berjumlah 36 orang siswa, yang 19 siswa laki-laki dan 17 siswa perempuan. Penelitian ini merupakan penelitian tindakan kelas yang dilaksanakan dalam dua siklus dengan tahap-tahapan setiap siklus meliputi perencanaan, pelaksanaan, observasi, pengamatan dan refleksi. Data mengenai hasil belajar dikumpulkan melalui metode tes, sedangkan data mengenai aktivitas belajar dikumpulkan dengan menggunakan metode observasi. Data yang telah dikumpulkan dianalisis dengan menggunakan analisis deskriptif kuantitatif. Hasil penelitian ini menunjukkan bahwa (1) Penerapan Pendekatan Contextual Teaching and Learning (CTL) dapat meningkatkan hasil belajar siswa yang ditunjukkan dengan rata-rata skor hasil belajar siklus I sebesar 80,81 dengan kategori baik selanjutnya meningkat menjadi 87,81 dengan kategori amat baik pada siklus II. (2) Penerapan Pendekatan Contextual Teaching and Learning (CTL) dapat meningkatkan aktivitas belajar siswa yang ditunjukkan dengan kategori cukup aktif selanjutnya meningkat menjadi aktif pada siklus II.
\end{abstract}

Kata Kunci: Aktivitas belajar, Hasil belajar, Pendekatan Contextual Teaching And Learning (CTL)

\begin{abstract}
This study aims to improve (1) the results of student learning and (2) the activity of student learning through the application of the approach Contextual Teaching and Learning (CTL) in social studies in class VIII SMP Negeri 3 Singaraja first academic year 2015/2016 the 36 students, 19 male students and 17 female students. This research is a classroom action research conducted in two cycles with each cycle stage-phases include planning, implementation, observation, observation and reflection. The outcome data collected through methods of learning tests, while data on learning activities are collected by using observation method. The collected data were analyzed using quantitative descriptive analysis.The results of this study indicate that (1) the application of the approach Contextual Teaching and Learning (CTL) can improve student learning outcomes as indicated by the average score of the first cycle of learning outcomes 80.81 with both categories is further increased to 87.81 with very good categories in the second cycle. (2) application of the approach Contextual Teaching and Learning (CTL) can improve students' learning activities indicated categories is further increased active enough to be active in the second cycle.
\end{abstract}

Keywords: Activities of learning, learning outcomes, approach Contextual Teaching And Learning (CTL) 


\section{PENDAHULUAN}

Rendahnya aktivitas dan hasil belajar siswa kelas VII I SMP Negeri 3 Singaraja disebabkan karena suasana pembelajaran masih kaku dan proses pembelajaran masih terpusat pada satu arah, sehingga siswa pasif saat guru menerangkan atau menyampaikan materi pelajaran, dan materi pelajaran yang disampaikan hanya menggunakan metode ceramah sehingga siswa cendrung bosan dan kurang memahami makna dari materi yang diajarkan karena siswa hanya mendengarkan dan mencatat serta guru kurang memanfaatkan media yang ada dalam proses pembelajaran

Permasalahan tersebut memberikan akibat terhadap rendahnya hasil belajar siswa kelas VII I dalam mata pelajaran IPS. Hal ini dapat diketahui berdasarkan hasil observasi dan wawancara kepada guru IPS Kelas VII I SMP Negeri 3 Singaraja. Hasil wawancara terhadap proses pembelajaran IPS di SMP Negeri 3 Singaraja ditemukan beberapa permasalahan antara lain : 1) hasil belajar siswa masih sangat rendah, 2) pada saat proses pembelajaran siswa kurang memperhatikan makna dari materi yang telah diberikan, 3) minat belajar siswa terhadap mata pelajaran IPS sangat rendah. Hasil wawancara peneliti dengan siswa SMP Negeri 3 Singaraja yaitu siswa menyatakan pembelajaran IPS sangat membosankan hal ini di karenakan pembelajaran yang terdiri dari hafalan belaka dan pembelajaran IPS dianggap pelajaran yang hanya mempelajari materi teori-teori yang membuat siswa gampang mengantuk pada saat pembelajaran berlangsung. Hal ini dapat dilihat pada perolehan data awal dengan jumlah siswa 36 orang. Data hasil belajar siswa diambil dari data ulangan harian siswa yang diperoleh pada saat observasi awal yaitu Dari perolehan data awal dengan jumlah siswa 36 orang dikategorikan sangat aktif sebanyak 2 orang $(2,9 \%)$, siswa yang aktif sebanyak 8 orang $(23,2 \%)$, siswa yang cukup aktif sebanyak 18 orang $(50, \%)$, dan siswa yang kurang aktif sebanyak 8 orang $(23,2 \%)$. Jadi dari data tersebut dapat diketahui bahwa sebagian besar siswa kelas VII I berada pada kategori cukup aktif pada Mata Pelajaran IPS, sedangkan untuk data hasil belajar Mata Pelajaran IPS diambil dari hasil ulangan harian pertama yang diperoleh pada saat observasi awal yaitu siswa yang tuntas sebanyak 2 orang $(5,8 \%)$ dan siswa yang tidak tuntas sebanyak $34(94,2 \%)$. Hasil belajar dikatakan tuntas apabila berada pada persentase hasil belajar $80 \%-100 \%$.

Hasil belajar dan aktivitas belajar yang belum mencapai ketuntasan ini merupakan permasalahan yang disebabkan oleh beberapa faktor melimuti 1). Kegiatan belajar mengajar di kelas didominasi oleh guru. Guru sebagai sumber pengetahuan dan lebih banyak menggunakan metode ceramah. Kondisi seperti ini mengakibatkan kelas menjadi pasif selama proses pembelajaran, 2). Proses pembelajaran belum mengaitkan materi pelajaran dengan kehidupan sehari-hari, ini mengakibatkan pelajaran yang disampaikan kurang bermakna bagi siswa 3). Siswa yang pintar cenderung mendominasi, sehingga siswa yang tidak aktif kurang memiliki kesempatan untuk mencoba sehingga berdampak pada ketuntasan hasil belajar siswa. Dan 4). Kurangnya pemanfaatan media lingkungan dalam pembelajaran siswa contohnya lingkungan fisik atau alam, lingkungan sosial budaya terutama di lingkungan sekitar siswa. Faktor-foktor tersebut disebabkan karena pemilihan metode pembelajaran yang di gunakan tidak sesuai atau kurang menarik sehingga pembelajaran menjadi membosankan bagi siswa.

Penerapan pendekatan CTL akan mampu mengatasi permasalahan dalam pembelajaran seperti yang telah disebutkan diata, karena: 1) pendekatan CTL dapat memberikan kesempatan belajar yang lebih luas dan suasana yang kondusif pada siswa untuk memperoleh dan mengembangkan pengetahuan, sikap, nilai, serta keterampilan-keterampilan sosial yang bermanfaat bagi ehidupan masyarakat. 2) proses pembelajaran berlangsung seca alamiah dalam bentuk kegiatan siswa bekerja dan mengalami, bukan transfer pengetahuan dari guru ke siswa. 3) pendekatan CTL menyajikan suatu konsep yang mengaitkan materi 
pelajaran yang dipelajari siswa dengan situasi dunia nyata siswa dan mendorong siswa membuat hubungan antara pengetahuan yang dimilikinya dengan penerapanya dalam kehidupan mereka sehari-hari, sehingga pelajaran akan menjadi lebih berarti dan bermakna serta menyenangkan. 4) pendekatan CTL melibatkan tujuh komponen utama dalam pembelajaran

Pembelajaran kontekstul adalah konsep belajar yang membantu guru menghubungkan antara materi pelajaran yang dikaitkan dengan situasi dunia nyata siswa dan mendorong siswa membuat hubungan antara pengetahuan yang dimilikinya dengan penerapanya dalam kehidupan sehari-hari (Johnson, 2011)..

Ilmu Pengetahuan Sosial (IPS) merupakan salah satu mata pelajaran yang sudah diberikan mulai dari SD, SMP, sampai dengan SMA dimana mata pelajaran IImu Pengetahuan Sosial (IPS) mengkaji seperangkat peristiwa, fakta, konsep, dan generalisasi yang berkaitan dengan isu sosisl. Pada jenjang SMP mata pelajaran IPS memuat materi Geografi, Sejarah, Sosiologi, dan Ekonomi.

Pelajaran IPS yang mengkaji
tentang kehidupan sosial masyarakat
memiliki karakteristik dalam proses
pembelajaran yang dilaksanakan.
Pendekatan pembelajaran yang sesuai
dengan karakteristik Ilmu Pengetahuan
Sosial adalah Pendekatan pembelajaran
Contextual Teaching and Learning (CTL).
Karakteristik dari pembelajaran Contextual
Teaching And Learning Wina Sanjaya
(2006:114) menyatakan dalam CTL
pembelajaran merupakan mengaktifkan
pengetahuan yang sudah ada artinya apa
yang akan dipelajari tidak terlepas dari
pengetahuan yang sudah dipelajari, dengan
demikian pengetahuan yang akan diperoleh
siswa pengetahuan yang utuh yang
memiliki keterkaitan satu sama lain.
Dengan konsep ini, hasil pembelajaran
diharapkan lebih bermakna bagi siswa.
Proses pembelajaran yang belangsung
secara alami dengan bentuk kegiatan siswa
dalam proses pembelajaran

Berdasarkan pemaparan di atas perlu dilakukan penelitian yang berkenaan dengan judul Penerapan Pendekatan Pembelajaran CTL (Contextual Teaching And Learning) Pada Mata Pelajaran IPS Untuk Meningkatkan Hasil Belajara Dan Aktivitas Belajar Siswa Kelas VII I SMP Negeri 3 Singaraja Tahun Ajaran 2015/2016

Penelitian ini bertujuan untuk (1) mengetahui.Peningkatan hasil belajar mata pelajaran IPS siswa kelas VII I di SMP Negeri 3 Singaraja tahun ajaran 2015/2016 melalui pendekatan pembelajaran CTL (Contextual Teaching and Learning) .(2) Peningkatan aktivitas belajar pada mata pelajaran IPS siswa kelas VII I SMP Negeri 3 Singaraja melalui pendekatan pembelajaran CTL (Contektual Teaching And Learning) .

\section{METODE}

Penelitian ini dirancang dengan menggunakan Penelitian Tindakan Kelas (PTK) yang dilaksanakan guna meningkatkan hasil belajaran dan Aktivitas belajarsiswa. Penelitian ini dilaksanakan dengan empat tahap kegiatan yang meliputi perencanaan tidakan, pelaksanaan tindakan, pengamatan dan refleksi Sebelum melakukan penelitian, peneliti (1), sebelum melaksanakan tindakan, terlebih dahulu peneliti merencanakan secara seksama jenis tindakan yang akan dilakukan, kedua (2) setelah rencana disusun secara matang, barulah tindakan dikalukan. Ketiga (3) bersamaan dengan dilaksanakanya tindakan, peneliti mengamati proses pelaksanaan tindakan itu sendiri dan akibat yang ditimbulkannya. Keempat (4), berdasarkan hasil pengamatan tersebut, peneliti kemudiaan melakukan refleksi atas tindakan yang telah dilakukan.

Kegiatan refleksi awal ini meliputi wawancara dan observasi kelas dengan guru IPS Kelas VII SMP Negeri 3 Singaraja. Observasi dan wawancara dilaksanakan untuk memproleh gambaran yang lebih jelas mengenai masalah yang dihadapi di sekolah bersangkutan yang terkait dengan pelajaran IPS. Hasil wawancara dan observasi kelas menunjukan bahwa 
aktivitas dan hasil belajar siswa masih rendah yang disebabkan guru dalam pembelajaran masih menerapkan metode, model dan pendekatan pembelajaran konvensional. Meskipun guru sudah mengkombinasikan dengan metode tanya jawab dan diskusi dalam kegiatan belajar mengajar ternyata masih belum dapat meningkatkan aktivitas belajar siswa secara optimal sehingga berpengaruh pada hasil belajar.

Rencana tindakan pada penelitian ini adalah rencana kolaborasi dengan guru mata pelajaran IPS, menganalisi masalah yang ditemukan dalam observasi, merencanakan penerapan pendekatan pembelajaran CTL (Contextual Teaching and Learning) untuk mengatasi masalah yang muncul, menyiapkan instrumen menerapkan pendekatan pembelajaran CTL (Contextual Teaching and Learning). aktivitas dan hasil belajar siswa.

Lokasi Penelitian ini dilakukan di kelas VII I bertempat di SMP Negeri 3 Singaraja Jalan Pulau Kalimantan No. 1 Singaraja. Subjek penelitian ini adalah siswa kelas VII I SMP Negeri 3 Singaraja yang berjumlah 36 orang siswa.Objek penelitian ini adalah penerapan model pembelajran CTL (Contextual Teaching and Learning), hasil belajar IPS dan Aktivitas Belajar. Jenis data menurut sumbernya. Data primer, berupa data aktivitas belajar dan data hasil belajar siswa serta penerapan pendekatan pembelajaran CTL (Contextual Teaching and Learning). Jenis data menurut sifatnya data yang digunakan dalam penelitian ini adalah jenis data kuantitatif, berupa data hasil belajar siswa dan data aktivitas belajar. Metode Pengumpulan Data yang digunaka adalah (1) Metode tes Dalam penelitian ini, metode tes digunakan untuk mengumpulkan data tentang pemahaman konsep siswa. Tes yang digunakan adalah tes esai. (2) Metode observasi metode ini digunakan untuk mengumpulkan data hasil belajar siswa dalam proses pembelajaran. Alat pengumpulan datanya berupa lembar observasi. (3) Metode Dokumentasi adalah mengumpulkan data dengan cara mengalir atau mengambil data - data dari catatan, dokumentasi, administrasi yang sesuai dengan masalah yang diteliti. Data ini dapat bermanfaat bagi peneliti untuk menguji, menafsirkan bahkan untuk meramalkan jawaban dari permasalahan peneliti.(4) Metode ini diperlukan pendidik untuk tujuan mengungkapkan atau menanyakan lebih lanjut hal - hal yang kurang jelas informasinya. Jadi dapat disimpulkan tehnik wawancara merupakan metode pengumpulan data dengan cara tanya jawab sepihak yang dilakukan secara sistematis dan berlandaskan kepada tujuan penelitian. Dalam peelitian ini peneliti melakukan wawancara dengan guru kelas dan siswa.

Instrumen penelitian merupakan alat bantu bagi peneliti di dalam menggunakan metode pengumpulan data" (Arikunto, 2002:101). Data yang dikumpulkan dalam penelitian ini adalah data mengenai aktivitas belajar siswa dan hasil belajar siswa.

Data aktivitas belajar siswa dianalisis dengan menggunakan lembar observasi aktivitas belajar siswa. Caranya dengan mengamati secara langsung kegiatan yang dilakukan siswa saat proses pembelajaran berlangsung. Penilaiannya dilakukan dengan melihat deskripsi dari lembar observasi aktivitas belajar siswa yang tertuang di dalam instrumen penelitian

Teknik analisis data yang digunakan pada penelitian ini adalah analisis deskriptif kuantitatif.

Data aktivitas siswa diamati dan dicatat dalam lembar observasi, selanjutnya dianalisis secara deskriptif. Kriteria yang digunakan dalam menggolongkan aktivitas belajar siswa disusun berdasarkan rata-rata skor aktivitas belajar siswa secara klasikal $(\mathrm{X})$, Mean ideal $(\mathrm{Mi})$, dan Standar Deviasi ideal (SDi). Menurut Koyan (2012:21) rumus untuk Mi dan SDi adalah sebagai berikut.

$\mathrm{Mi} \quad \stackrel{\mathrm{I}}{=} \times$ (skor tertinggi ideal + skor terendah ideal)

SDi $\quad=\frac{1}{6} \times$ (skor tertinggi ideal - skor terendah ideal)

Keterangan : Mi= Mean ideal (angka rata-rata ideal) 


$$
\text { SDi = Standar Deviasi ideal }
$$

Adapun cara pemberian skor tentang aktivitas belajar siswa adalah setiap deskripsi dari masing-masing indikator aktivitas belajar siswa yang tampak selama observasi, dicatat pada lembar observasi dengan memberikan skor. Apabila sebuah deskripsi tidak tampak, maka skor 1 dan sebaliknya apabila deskripsi tampak, maka perolehan skor dalam rentangan 2 hingga 4. Skor tertinggi aktivitas belajar siswa adalah 48 dan skor terendah adalah 12. Dengan demikian perhitungan Mi dan SDi adalah sebagai beriku.

$\mathrm{Mi}=\frac{1}{2} \times$ (skor tertinggi ideal + skor terendah ideal)

$$
\begin{aligned}
& =\frac{1}{2} \times(15+0) \\
& =7,5
\end{aligned}
$$

$\mathrm{SDi}=\frac{1}{6} \times$ (skor tertinggi ideal - skor terendah ideal)

$$
\begin{aligned}
& =\frac{1}{6} \times(15-0) \\
& =2,5
\end{aligned}
$$

Dari data aktivitas yang terkumpul selanjutnya ditentukan rata-rata persentase aktivitas belajar siswa secara klasikal $(X)$ dengan rumus sebagai berikut

$$
\overline{\mathrm{X}}=\frac{\Sigma x}{N} x 100 \%
$$

(Sudjana,2004:109)

Keterangan:

$\sum X=$ jumlah seluruh skor aktivitas belajar siswa

$N \quad$ = banyaknya subjek (siswa)

$\bar{X} \quad=$ rata-rata skor aktivitas siswa (klasikal)

Data hasil belajar siswa diperoleh setelah diimplementasikannya model pembelajaran Contextual Teaching and Learning dapat dihitung dengan menghitung skor rata-rata kelas $(X)$ dengan rumus sebagai berikut.

$$
X=\frac{\bar{\Sigma} X}{\mathbf{N}}
$$

Keterangan :

$\begin{array}{ll}\mathrm{X} & =\text { nilai rata-rata }(\text { mean) } \\ \sum_{\mathrm{N}} \mathrm{X} & =\text { jumlah total skor siswa } \\ & =\text { jumlah siswa }\end{array}$

Ketuntasan hasil belajar siswa dapat ditentukan dengan menghitung Daya Serap Siswa (DSS) dengan rumus sebagai berikut.

DSS

$\underline{\text { Jumlah total nilai yang dicapai siswa }} \times 100 \%$ Jumlah total skor maksimum

Ketuntasan Belajar (KB) dapat dihitung dengan menggunakan rumus sebagai berikut.

$$
\mathrm{KB} \frac{\text { Jumlah Siswa yang }}{\text { Jumlah Siswa }} \mathrm{x}
$$

Indikator keberhasilan penelitian tindakan kelas untuk mengetahui hasil belajar siswa dan Aktivitas belajar siswa antara lain : berpedoman pada Kriteria Ketuntasan Minimal (KKM) yang telah di terapkan dalam mata pelajaran IPS bagi siswa kelas VII I SMP Negeri 3 Singaraja yaitu dengan KKM sebesar 75 .

\section{HASIL DAN PEMBAHASAN}

\section{HASIL}

Hasil belajar siswa pada mata pelajaran ekonomi dengan menerapkan pendekatan pembelajaran CTL (Contextual Teaching and Learning) dalam dua kali pertemuan, Hasil perolehan data hasil belajar skor tertinggi 96 dan skor terendah 60 . Secara lebih lengkap, data hasil belajar siswa digambarkan pada tabel 4.1 berikut. 
Tabel 1 Data Hasil Belajar Siswa Pada Siklus I

\begin{tabular}{|c|c|c|c|c|}
\hline No & Skor & Kategori & Jumlah Siswa & Persentase \\
\hline 1 & $85-100$ & Sangan baik & 12 & $33,33 \%$ \\
\hline 2 & $80-84$ & Baik & 6 & $16,67 \%$ \\
\hline 3 & $65-79$ & Cukup & 17 & $47,22 \%$ \\
\hline 4 & $55-64$ & Kurang & 1 & $27,78 \%$ \\
\hline 5 & $0-54$ & Sangat kurang & 0 & $0 \%$ \\
\hline Jumlah & & & 36 & $100 \%$ \\
\hline
\end{tabular}

Dari data tersebut dapat dilihat bahwa, siswa yang memperoleh nilai pada rentangan 85-100 sebanyak 12 orang dengan persentase $33,33 \%$, siswa yang memperoleh nilai pada rentangan 80-84 sebanyak 6 orang dengan persentase $16,67 \%$, siswa yang memperoleh nilai pada rentangan 65-79 sebanyak 17 orang dengan persentase $47,22 \%$, siswa yang memperoleh nilai pada rentangan 55-64 sebanyak 1 orang dengan persentase
$2,78 \%$, dan tidak ada siswa yang memperoleh nilai pada rentangan 0-54. Rata-rata hasil belajar siswa pada siklus I adalah 80,81 dengan kategori Baik.

Berdasarkan hasil belajar siswa dan Kriteria Ketuntasan Minimal (KKM) yang ditetapkan yakni 75, maka dapat diketahui jumlah siswa yang tuntas dan belum tuntas dalam pembelajaran Ekonomi pada siklus I. Lebih jelasnya ketuntasan belajar siswa tersebut dapat dilihat pada tabel 4.2 berikut.

Tabel 2 Ketuntasan Belajar Siswa Pada Siklus I

\begin{tabular}{ccc}
\hline Keterangan & Jumlah Siswa & Persentase \\
\hline Tuntas & 30 & $83,33 \%$ \\
Belum Tuntas & 6 & $16,67 \%$ \\
Jumlah & 36 & $100 \%$ \\
\hline
\end{tabular}

Hasil perolehan data aktivitas

belajar pada pelaksanaan proses diperoleh

data aktivitas belajar siswa pada siklus I

sebagai berikut.

Tabel 3 Data Aktivitas Belajar Siswa Pada Siklus I

Sebaran Aktivitas Belajar Siswa

\begin{tabular}{|c|c|c|c|c|}
\hline \multirow[t]{2}{*}{ Kategori } & \multicolumn{2}{|c|}{ Pertemuan Pertama } & \multicolumn{2}{|c|}{ Pertemuan Kedua } \\
\hline & $\begin{array}{l}\text { Jumlah } \\
\text { siswa }\end{array}$ & Persentase & Jumlah siswa & Persentase \\
\hline Sangat Aktif & 0 & $0 \%$ & 0 & $0 \%$ \\
\hline Aktif & 3 & $8,33 \%$ & 16 & $44,44 \%$ \\
\hline Cukup Aktif & 10 & $27,78 \%$ & 18 & $50 \%$ \\
\hline Kurang Aktif & 23 & $63,89 \%$ & 2 & $5,56 \%$ \\
\hline Sangat Kurang aktif & 0 & $0 \%$ & 0 & $0 \%$ \\
\hline Jumlah & 36 & $100 \%$ & 36 & $100 \%$ \\
\hline
\end{tabular}

Berdasarkan tabel di atas, dapat diketahui bahwa jumlah siswa Kelas VII
SMP Negeri 3 Singaraja yang menjadi subjek penelitian adalah 36 orang siswa. Pada pertemuan pertama, aktivitas belajar siswa yang berada pada kategori sangat 
aktif tidak ada (0\%), aktivitas belajar siswa yang berada pada kategori aktif sebanyak 3 orang $(8,33 \%)$, aktivitas belajar siswa yang berada pada kategori cukup aktif sebanyak 10 orang $(27,78 \%)$, aktivitas belajar siswa yang berada pada kategori kurang aktif sebanyak 23 orang $(63,89 \%)$, dan aktivitas belajar siswa yang berada pada kategori sangat kurang aktif tidak ada $(0 \%)$. Sedangkan pada pertemuan kedua, aktivitas belajar siswa yang berada pada kategori sangat aktif tidak ada (0\%), aktivitas belajar siswa yang berada pada kategori aktif sebanyak 16 orang $(4,44 \%)$, aktivitas belajar siswa yang berada pada kategori cukup aktif sebanyak 18 orang $(50 \%)$, aktivitas belajar siswa yang berada pada kategori kurang aktif sebanyak 2 orang $(5,56 \%)$, dan aktivitas belajar siswa yang berada pada kategori sangat kurang aktif tidak ada ( $0 \%)$.

Hasil belajar siklus II Berdasarkan analisis data yang telah dilakukan, didapatkan skor tertinggi 99 dan skor terendah 73. Secara lebih lengkap, data hasil belajar siswa digambarkan pada tabel 4.2 berikut.

Tabel 4 Data Hasil Belajar Siswa Pada Siklus II

\begin{tabular}{ccccc}
\hline No & Skor & Kategori & Jumlah Siswa & Persentase \\
& & & & \\
\hline 1 & $85-100$ & Sangan baik & 23 & $63,89 \%$ \\
2 & $80-84$ & Baik & 12 & $33,33 \%$ \\
3 & $65-79$ & Cukup & 1 & $2,78 \%$ \\
4 & $55-64$ & Kurang & 0 & $0 \%$ \\
5 & $0-54$ & Sangat kurang & 0 & $0 \%$ \\
& Jumlah & & 36 & $100 \%$ \\
\hline
\end{tabular}

64 dan rentangan 0-54. Rata-rata hasil

Dari data tersebut dapat dilihat bahwa, siswa yang memperoleh nilai pada rentangan 85-100 sebanyak 23 orang dengan persentase $63,89 \%$, siswa yang memperoleh nilai pada rentangan 80-84 sebanyak 12 orang dengan persentase $33,33 \%$, siswa yang memperoleh nilai pada rentangan 65-79 sebanyak 1 orang dengan persentase $2,78 \%$, dan tidak ada siswa yang memperoleh nilai pada rentangan 55- belajar siswa pada siklus I adalah 87,81 dencan katenori Sannat Baik

Berdasarkan hasil belajar siswa dan Kriteria Ketuntasan Minimal (KKM) yang ditetapkan yakni 75, maka dapat diketahui jumlah siswa yang tuntas dan belum tuntas dalam pembelajaran Ekonomi pada siklus II. Lebih jelasnya ketuntasan belajar siswa tersebut dapat dilihat pada tabel 4.3 berikut.

Tabel 5 Ketuntasan Belajar Siswa Pada Siklus II

\begin{tabular}{ccc}
\hline Keterangan & Jumlah & Persentase \\
& Siswa & \\
\hline Tuntas & 35 & $97,22 \%$ \\
Belum Tuntas & 1 & $2,78 \%$ \\
Jumlah & 36 & $100 \%$ \\
\hline
\end{tabular}

Data aktivitas belajar siswa pada siklus II sebagai berikut 
Tabel 6 Data Aktivitas Belajar Siswa Pada Siklus II

\section{Sebaran Aktivitas Belajar Siswa}

\begin{tabular}{|c|c|c|c|c|}
\hline \multirow[t]{2}{*}{ Kategori } & \multicolumn{2}{|c|}{ Pertemuan Pertama } & \multicolumn{2}{|c|}{ Pertemuan Kedua } \\
\hline & $\begin{array}{l}\text { Jumlah } \\
\text { siswa }\end{array}$ & Persentase & $\begin{array}{l}\text { Jumlah } \\
\text { siswa }\end{array}$ & Persentase \\
\hline Sangat Aktif & 5 & $13,89 \%$ & 8 & $22,22 \%$ \\
\hline Aktif & 29 & $80,56 \%$ & 26 & $72,22 \%$ \\
\hline Cukup Aktif & 2 & $5,56 \%$ & 2 & $5,56 \%$ \\
\hline Kurang Aktif & 0 & $0 \%$ & 0 & $0 \%$ \\
\hline Sangat & 0 & $0 \%$ & 0 & $0 \%$ \\
\hline Kurang aktif & & & & \\
\hline Jumlah & 36 & $100 \%$ & 36 & $100 \%$ \\
\hline
\end{tabular}

diketahui bahwa jumlah siswa Kelas VII

SMP Negeri 3 Singaraja yang menjadi subjek penelitian adalah 36 orang siswa. Tabel di atas juga menunjukkan, pada pertemuan pertama, aktivitas belajar siswa yang berada pada kategori sangat aktif sebanyak 5 orang (13,89\%), aktivitas belajar siswa yang berada pada kategori aktif sebanyak 29 orang $(80,56 \%)$, aktivitas belajar siswa yang berada pada kategori cukup aktif sebanyak 2 orang $(5,56 \%)$, dan tidak ada aktivitas belajar siswa yang berada pada kategori kurang aktif dan sangat kurang aktif. Pada pertemuan kedua, aktivitas belajar siswa yang berada pada kategori sangat aktif sebanyak 8 orang $(22,22 \%)$, aktivitas belajar siswa yang berada pada kategori aktif sebanyak 26 orang $(72,22 \%)$, aktivitas belajar siswa yang berada pada kategori cukup aktif sebanyak 2 orang $(5,56 \%)$, dan tidak ada aktivitas belajar siswa yang berada pada kategori kurang aktif dan sangat kurang aktif

\section{PEMBAHASAN}

Berdasarkan hasil penelitian yang telah dilaksanakan selama dua siklus dengan menerapkan pendekatan Contextual Teaching And Learning (CTL), dapat meningkatkan aktivitas dan hasil belajar siswa. Pada siklus I pertemuan pertama, rata-rata nilai aktivitas belajar siswa sebesar 6,47 dan pada pertemuan kedua mengalami peningkatan menjadi 8,19 , sehingga nilai rata-rata aktivitas belajar siswa pada siklus I sebesar 7,4 dengan kategori cukup aktif. Hal ini menunjukkan bahwa aktivitas belajar siswa masih belum memuaskan sehingga masih perlu untuk diadakan perbaikan. Pendekatan contextual teaching and learning (CTL) mampu meningkatkan hasil belajar siswa yang dapat dilihat dari adanya kenaikan nilai rata-rata kelas dari 57,35 pada observasi awal menjadi 80,81 pada akhir siklus I. Ketuntasan belajar klasikal juga meningkat sebesar $77,5 \%$ dari $5,8 \%$ pada observasi awal menjadi $83,3 \%$ pada akhir siklus I.

Pada siklus II pertemuan pertama rata-rata nilai aktivitas belajar siswa sebesar 9,90 dan pada pertemuan kedua meningkat menjadi 10,027 sehingga ratarata nilai aktivitas belajar siswa pada siklus II sebesar 9,8475 dengan kategori aktif dibandingkan pada siklus I, skor rata-rata aktivitas belajar siswa adalah 7,4 dengan kategori cukup aktif. Hal ini menunjukkan bahwa aktivitas siswa mengalami peningkatan dari sebelumnya. Dengan tercapainya aktivitas yang telah disebutkan di atas tentunya hal ini menyebabkan aktivitas belajar dan hasil belajar IPS dari siklus sebelumnya. Siswa belajar dan beraktivitas sendiri untuk memperoleh pengalaman, pengetahuan dan tingkah laku lainnya serta mengembangkan keterampilan yang bermakna sehingga kegiatan atau aktivitas belajar siswa merupakan dasar untuk mencapai hasil belajar yang optimal. Aktivitas dalam proses pembelajaran merupakan salah satu indikator adanya keinginan untuk belajar. Peningkatan aktivitas belajar dan hasil belajar siswa ini disebabkan karena siswa diberikan peluang untuk mengembangkan kemampuan berfikirnya, sehingga siswa mempunyai pemikiran sendiri dari 
kehidupan mereka sehari-hari dalam mengerjakan soal yang diberikan dan materi yang dipelajari akan lebih mudah untuk dipahami. Hal ini sejalan dengan teori yang mendasari penerapan pendekatan Contextual Teaching And Learning (CTL). Kemudian nilai rata-rata hasil belajar hasil belajar siswa pada silkus II mengalami peningkatan cukup tinggi yaitu dari 80,81 pada akhir siklus I menjadi 87,81 pada akhir siklus II dengan kategori amat baik. Selain itu, ketuntasan klasikal juga mengalami peningkatan yang dapat dikatakan sangat tinggi yaiti sebesar $13,9 \%$ dari $83,3 \%$ pada akhir siklus I menjadi $97,2 \%$ pada akhir siklus II.

Data tersebut menunjukan bahwa penerapan pendekatan Contextual Teaching and Learning (CTL), dapat meningkatkan aktivitas dan hasil belajar yang dilihat dari adanya peningkatan terhadap aktivitas siswa dalam mengikuti pembelajaran di dalam kelas seperti sebagian besar siswa sudah terlihat aktif dalam menemukan atau memecahkan solusi dari permasalahan yang ada, siswa sudah berani untuk mengajukan pertanyaan ataupun mengemukakan pendapatnya dalam diskusi serta siswa berani untuk memberikan simpulan di akhir pembelajaran mengenai materi yang telah dipelajarai. Penerapan pendekatan Contextual Teaching and Learning (CTL), juga dapat meningkatkan hasil belajar siswa yang dilihat dari adanya peningkatan nilai rata-rata hasil belajar siswa dari siklus I sampai dengan siklus II, dengan rata-rata kenaikan sebesar 7 dari rata-rata siklus I sebesar 80,81 menjadi 87,81 pada siklus II.

Pembelajaran dengan menggunakan pendekatan Contextual Teaching and Lerning (CTL) dapat membantu siswa untuk memecahkan permasalahan yang telah diberikan dari pengalaman mereka sehari-hari di keluarga dan di lingkungan sekitar mereka. hal ini sejalan dengan pernyataan Oemar Hamalik (2009) yang menyatakan bahwa " Pengajaran efektif adalah pengajaran yang menyediakan kesempatan belajar sendiri dan beraktivitas sendiri kepada siswa. Siswa belajar dan beraktivitas sendiri untuk memperoleh pengalaman, pengetahuan dan tingkah laku lainnya serta mengembangkan keterampilannya yang bermakna sehingga kegiatam atau aktivitas belajar siswa merupaan dasar untuk mencapai hasil belajar yang optimal" dalam hal ini pendekatan ini dapat digunakan dalam meningkatkan aktivitas dan hasil belajar siswa, peningkatan aktivitas dan hasil belajar siswa ini disebabkan karena siswa diberikan peluang untuk mengembangkan pengetahuanpengetahuan yang telah didapat dalam kehidupan mereka sehari-hari siswa sehingga siswa mempunyai pemikiran sendiri dalam mengerjakan soal yang diberikan dan materi yang dipelajari akan lebih mudah untuk dipahami. Hal ini sejalan dengan teori yang mendasari penerapan pendekatan Contextual Teaching and Learning yang dikembangkan oleh Yamin (2013:178) yang menyatakan bahwa pendekatan pembelajaran Contextual Teaching and Learning (CTL) merupakan proses pembelajaran holistik dan membantu peserta didik untuk memahami makna materi ajar dengan mengaitkannya terhadap konteks kehidupan sehari-hari (konteks, pribadi, sosial dan kultur), sehingga siswa memiliki pengetahuan sendiri secara aktif pemahamannya. Berdasarkan hasil tindakan pada siklus I dan siklus II dapat dikatakan bahwa penerapan pendekatan Contextual Teaching and Learning dapat meningkatkan aktivitas dan hasil belajar siswa kelas VIII I SMP Negeri 3 Singaraja pada mata pelajaran IPS Terpadu tahun ajaran 2014/2016

Dari paparan diatas, secara umum pendekatan Contextual Teaching and Learning (CTL) sudah dapat meningkatkan aktivitas dan hasil belajar siswa. Dengan kata lain penelitian ini sudah dapat menjawab pertanyaan dari rumusan masalah sehingga penelitian ini dapat dikatakan berhasil karena semua kriteria yang diterapkan sudah terpenuhi, jadi dapat disimpulkan bahwa penerapan pendekatan Contektual Teaching and Learning dapat meningkatkan aktivitas dan hasil belajar siswa kelas VIII. 


\section{SIMPULAN DAN SARAN SIMPULAN}

Berdasarkan hasil dan pembahasan penelitian yang telah dilakukan, maka dapat disimpulkan hal-hal sebagai berikut.

1. Penerapan pendekatan pembelajaran Contextual Teaching and Learning (CTL) dapat meningkatkan aktivitas belajar siswa pada mata pelajaran Ekonomi di Kelas VII SMP Negeri 3 Singaraja. Ratarata nilai aktivitas belajar pada siklus I sebesar 7,33 berada pada kategori cukup aktif. Sedangkan rata-rata nilai aktivitas belajar siswa pada siklus II meningkat menjadi 10,13 berada pada kategori Aktif.

2. Penerapan pendekatan pembelajaran Contextual Teaching and Learning (CTL) dapat meningkatkan hasil belajar siswa pada mata pelajaran Ekonomi di Kelas VII SMP Negeri 3 Singaraja. Rata-rata nilai hasil belajar pada siklus I sebesar 80,81 berada pada kategori baik. Sedangkan rata-rata nilai hasil belajar siswa pada siklus II meningkat menjadi 87,81 berada pada kategori sangat baik

\section{SARAN}

Berdasarkan simpulan yang dipaparkan di atas, maka dapat dungkapkan saran terkait dengan hasil penelitian ini dalah sebagai berikut

1. Kepada guru SMP Negeri 3 Singaraja agar dapat menerapkan pembelajaran Contextual Teaching and Learning (CTL) sebagai salah satu pendekatan pembelajaran yang dipilih dalam pembelajaran IPS. Karena pendekatan pembelajaran Contextual Teaching and Learning (CTL) ini dapat meningkatkan hasil dan aktivitas belajar siswa sehingga tujuan pembelajaran yang diharapkan dapat tercapai.

2. Kepada siswa-siswi yang dijadikan subjek penelitian selanjutnya lebih memperhatikan dan memahami pembelajaran yang diberikan, agar dapat menambah wawasan pengetahuan khususnya dalam mata pelajaran IPS maupun dlam mata pelajaran lain.

3. Kepada calon peneliti yang berminat untuk meneliti lebih lanjut dengan menggunakan pembelajaran Contextual Teaching and Learning (CTL) agar menggunakan pokok bahaan yang berbeda dan memperhatikan kendala-kendala yang dihadapi peneliti sebagai bahan pertimbangan untuk perbaikan dan penyempurnaan pelaksanaan penelitian berikutnya.

\section{DAFTAR PUSTAKA}

Agung, A.A Gede, 2005. Metodologi Penelitian Pendidikan. Singaraja:UNDIKSHA.

Agus Suprijono. Cooperative Learning. Teori dan Aplikasi Paikem. Yogyakarta: Pustaka Belajar.

Ahmadi, Abu dan J. Tri Prasetyo 1997. Strategi Belajar Mengajar. Bandung: CV Pustaka Setia.

Alwasilah A. Chaedar. 2006. Contextual Teaching And Learning: MenjadikanKegiatan Belajar Mengasyikkan Dan Bermakna. Bandung: Mizan Learning Center (MLC).

Arifin, Zainal. 1998. Evaluasi Instruksional Prinsip Teknik Prosedur. Bandung: Remaja Rosda Karya.

Arnyana, Putu Ida Bagus, 2004. Pengembangan Prangkat Model Belajar Berdasarkan Masalah Di Pandu Strategi Kooperatif Serta Pengaruh Implementasinya Terhadap Motivasi Dan Hasil Belajar Siswa Sekolah Menengah Atas Pada Pelajaran Ekosistem, Disertai.

Diterbitkan)Universitas Neger Malang: Pasca Sarjana Program Studi Pendidikan Biologi.

Arikunto, Suharsimi, dkk.2011.Penelitian Tindakan Kelas.Jakarta:Pt Bumi Aksara.

$\begin{array}{cc} & \text { Suharsimi.2009.Dasar-dasar } \\ \text { Evaluasi } & \text { Pendidikan.Jakarta:Pt } \\ \text { Bumi } & \text { Aksara }\end{array}$


p-ISSN : 2599-1418

e-ISSN : 2599-1426

Asma, Nur. 2006. Model Pembelajaran Kooperatif. Depdknas.

Aziz, Abdul W. 2007. Metode Dan ModelModel Mengajar. Bandung: PenerbitAlfabeta. Badan Standardisasi

Darma kesuma dkk.2010.Contektual Teaching and Learning ( Sebuah Panduan Awal dalam pengembangan proses belajar mengajar)Yogyakarta: RAHAYASA Research and Training.

Depdiknas. 2003. Pendekatan Kontekstual /Contextual Teaching and Learning (CTL). Dirjen Pendidikan Lanjutan Pertama

2003, Pendekatan Kontekstual (Contextual Teaching and Learning). Jakarta: Departemen Pendidikan Nasional Direktorat Jendral Pendidikan Dasar dan Menengah Direktorat Pendidikan Lanjutan Pertama.

--------, 2006. Permen 23 tahun 2006 tentang standar kopetensi lulusan untuk satuan pendidikan dasar dan memengah. Dirjen Pendidikan Lanjutan Pertama.

---------, 2007. Panduan Pembelajaran Kontekstual Sekolah Menengah Pertama. Jakarta: Depdiknas

Djiwandono.2002. Psikologi Pendidikan.Jakarta:PT Gramedia Widiasarana Indonesia.

Johnson E B. 2011. CTL (Contextual Teaching and Learning). Buku Ajar. Jakarta: Perpustakaan Nasional.

Harmalik, Oemar. 2003. Perencanaan Pembelajaran Berdasarkan Pendekatan Sisitem. Jakarta: PT. Bumi Aksara.

Nurhadi dan Gerrad Senduk Agus. 2003. Pembelajaran Kontekstual (ContextualTeaching And Learning/CTL) Dan Penerapannya Dalam KBK. Malang: Penerbit Universitas Universitas Negeri
Jurnal Pendidikan Ekonomi Undiksha

Volume 9 No.1 Tahun: 2017

Malang.tersedia

pada

http://library.um.ac.id/free-

contents/index.php/buku/detail/pe

mbelajaran-kontekstual-contextual-

teaching-and-learningctl-dan-

penerapannya-dalam-kbk-oleh-

nurhadi-burhan-yasin-agus-

gerrard-senduk-28747.html

(diakses pada tanggal 12 Maret 2016).

Komaidi dan Wijayanti. 2011. Penelitian

Tindakan Kelas. Yogyakarta:

Pustaka Insan Madani

Sagala, Syaiful.2012. Konsep dan Makna Pembelajaran. Bandung: Alfabeta

Sanjaya, Wina. 2006. Pembelajaran dalam Implementasi Kurikulum Berbasis Kompetensi. Jakarta: Prenada Media Group.

--------,Wina. 2007. Strategi Pembelajaran Berorientasi Standar Proses Pendidikan. Jakarta: Prenada Media Group

Sardiman 2004. Interaksi dan Motivasi Belajar mengajar. Jakarta: PT Raja Grapindo Persada.

---------, 2011 Interaksi dan Motivasi Belajar Mengajar, Jakarta: PT Rineka Cipta.

Selameto. 2003. Belajar dan Faktor-faktor yang Mempengaruhinya. Jakarta: Pt Rineka Cipta

Syarof Nursyah Ismail, 2010. Penerapan Model Pembelajaran CTL (Contextual Teaching And Learning) Pada Mata Pelajaran Sejarah Untuk meningkatkan Prestasi Belajar. Universitas Negeri Maulana Malik Ibrahim. Tersedia pada https://www.scribd.com/doc/17503 4584/Penerapan-ModelPembelajaran-Ctl-Contextual. (diakses pada tanggal 12 Maret 2016). 
Sudjana, Nana. 2006. Penilaian Hasil Proses Belajar Mengajar. Bandung: PT. Remaja Rosdakarya Offset.

--------, Nana 2010 Penilaian Hasil Proses BelajarMengajar. Bandung: Sinar Biru.

Sutisno,2012.Kreatif Mengembangkan Aktifitas Pembelajaran Berbasis TIK.Jakarta:Referensi.

Suyono dan Harianto,2011.Belajar dan pembelajaran.Bandung:PT Remaja Rosdakarya.

Sudijono,Anas.2012.Pengantar Evaluasi Pendidikan. Depok:Rajagrafindo Persada.

Suprijono. 2009. Cooperative Learning. Yogyakarta: Pustaka Belajar.

Taniredja, Tukiran dkk. 2011. Model-model Pembelajaran Inovatif. Bandung: Alfabeta

Trianto. 2010. Model Pembelajaran Terpadu. Surabaya: Bui Aksara.

Wahidmurni,dkk.2010.Evaluasi

Pembelajaran Kompetensi dan Praktik.Yogyakarta:Nuha Litera.

Yamin, Martinis. 2013. Paradigma Baru Pembelajaran. Jakarta: Referensi 